\title{
Evaluating the Potential for Soybean Culture in Romania Compared with the European Union
}

\author{
Elena ŞURCĂ $\breve{A}^{*}$ \\ Research Institute for Agriculture, Economy and Rural Development, Bucharest, Romania \\ *corresponding author: surca.elena@iceadr.ro
}

Bulletin UASVM Horticulture 75(1) / 2018

Print ISSN 1843-5262, Electronic ISSN 1843-536X

DOI:10.15835/buasvmcn-hort: 000217

\begin{abstract}
Soybean is a very popular plant for its wide use, and it is coming back to the attention of farmers due to its special importance in various sectors. Thus, the present study, aims to highlight Romania's position regarding the areas cultivated with this plant, grain and oil production, consumption per capita and also forage consumption in the zootechnical sector. Also, it will bring in the highlight aspects very important, like imports and exports for the period of 2000-2016 in order to assess the potential of soybean culture and its necessity on the territory of Romania. Due to the high demand for soybeans and / or soybean products, Romania has to resort to the European or world market in order to satisfy the demand for this product, mainly used in the livestock sector. Soybean culture will be analyzed in two different period, the first period will be the pre-accession (2000-2007) and the second one will be the post-accession (2007-2016) of Romanian to the European Union, thus reference will be made to genetically modified soybeans and their use on national and European territories.
\end{abstract}

Keywords: consumption, genetically modified soybeans, trade

\section{Introduction}

The soybean culture (Glycine $\max$, Fam. Fabaceae) originated in China was introduced in Europe in the XVII century, but until the XIX century it was rarely cultivated on the continent, with slightly increased cultivated areas at the beginning of the XX-th century and slightly declining during World War II. Soybean culture has been brought to the attention of farmers since 1950 due to its wide use, in human food as: oil, milk, tofu and flour etc. But also with uses in the livestock sector as forage both as green matter and also as grains, being rich in fats and proteins they are a basic component of the animal fodder.

Proteins (43\%) and fats (23\%) present in soybean make this plant superior in quality from other grain crops. The demand for soybeans at European level is supported, according to the sectorial study " Research on the regional market of oilseeds for the expansion of cross-border trade opportunities: Moldova, Romania, Ukraine ", by the main suppliers such as USA who has a market share of $36 \%$ and Brazil by $33 \%$. Soybean oil is one of the most important vegetable oils in the world due to its high utilization in the diverse sectors and also for the high demand at the global level. For example in the period $2012 / 2013$, soybean oil accounts for $27 \%$ of world vegetable oil production, the second place takes by the the palm oil (35\%) (He and Chen, 2013).

This plant has also industrial use so that the oil obtained after processing can be used as an ingredient in the production of lubricants, cosmetics, detergents, paints, fibers and plastics or biofuels following the trans-esterification process.

According to the same sectorial study mentioned above, the use of biodiesel soybean oil is steadily increasing, leading to increased domestic production and imports and exports, and the main supplier of soybean oil at European level being Argentina. 


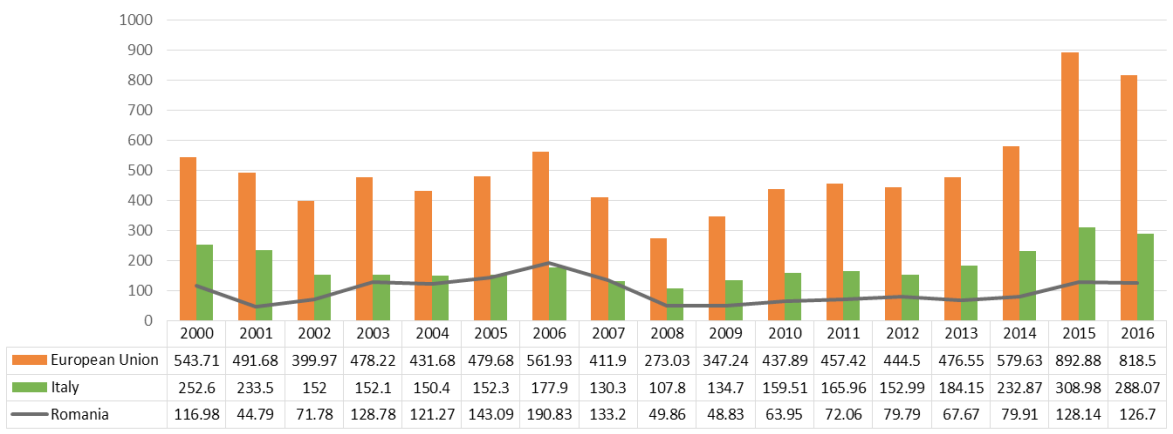

Figure 1. The area occupied by soybean at European level - thou ha Source: Eurostat-database, agriculture

There are several varieties of this crop according to the duration of the vegetation, so the soybean varieties can be defined by the maturity group as: extra-time, early, semi-finished, semilate and late.

In Romania there are cultivated 50 soybean varieties, according to the Official Catalog of Plant Varieties of Romania for the year 2015 developed by the State Institute for Testing and Registration of Soils (ISTIS), out of which 3 were radiated (Columna, Danubiana, Românesc 99) in 2012 and allowed to continue its marketing until 30.06.2015. Of the 50 cultivated varieties 10 varieties are of Romanian origin: Onix, Felix, Perla, Larisa TD, Darina TD, Malina TD, Caro TD produced by SCDA Turda and Oana F, Daciana and Triumph produced by INCDA Fundulea.

Until Romania's accession to the EU, it was cultivated genetically modified soy varieties. In 2000 Romania was the only European country where the cultivation of genetically modified soybeans was allowed (Băiceanu, 2015), while at European member state level through Council Directive No. 219 23/04/1990 the use of genetically modified micro-organisms in isolation was mandatory (Bertheau and Davison, 2011).

The aim of this study is to highlight the position of Romania for soybean culture at European level and to emphasize the fact that the national market can not support soybean demand. Although Romania meets all the conditions necessary for the cultivation of this plant, which has come out of the attention of the farmers immediately with the forbidden of genetically modified soybean.

\section{Materials and methods}

Taking into account the particular importance of soybean culture in different sectors, there will be analyzed the quantitative and qualitative characters from statistical data during 2000 to 2016, provided by National Institute of Statistics of Romania, Eurostat, Faostat, DG-AGRI, SoyStats, based on the genetically modified soybean legislation and also the analysis of existing documents in the literature.

Was used especially the comparative analysis method, taking into account the two pre-accession and post-accession periods specific to Romania, but also the position of Romania on the map of Europe regarding soybean culture.

In order to highlight the potential of soybean culture in Romania and its necessity at national level, there has been made a quantitative analysis of the data concerning the national consumption of this plant (food, zootechnical, industrial) as well as the imported soybean grain and oil quantities.

\section{Results and discussions}

The cultivated soybean area at the level of the European Union for the entire analyzed period is presented as a sinuous line (according to Fig. 1), the area decreasing by $49.8 \%$ in 2008 , reaching half of the soybean cultivated surface in 2000. A major influence that led to its decline is due to the U.E. Directive 2001/18/EEC, which regularizes the use in isolation of genetically modified organic material, and also the commercialization - import, processing, transformation of genetically modified organisms into industrial products, thus restricting the cultivation of genetically modified plants, including soybeans.

The country that occupies the most important position in soybean cultivation is Italy, registering the largest areas for almost the entire period under review, in 2000 it held $46 \%$ of the European Union area cultivated with soybeans, the remaining $54 \%$ being held by the other 14 member states of the Union at that time. In 2007, when Romania joined 


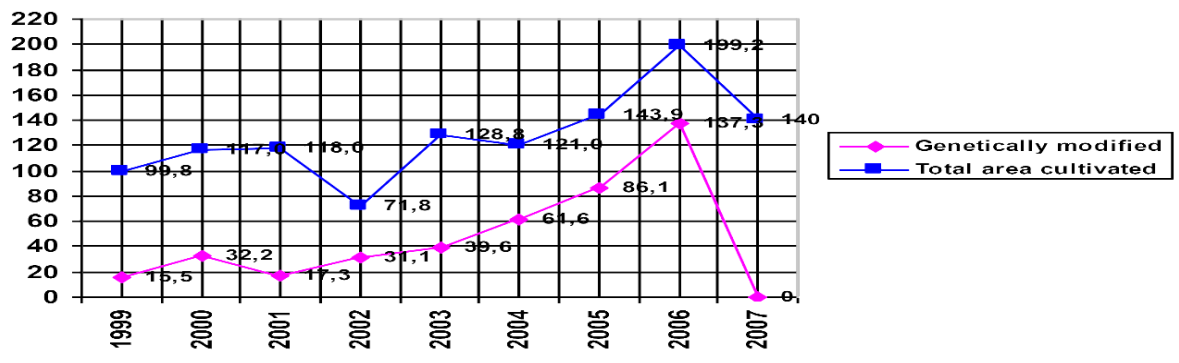

Figure 2. Total soybean cultivated surfaces at national level and the areas with genetically modified soybean varieties - thou ha Source: Băiceanu (2015)

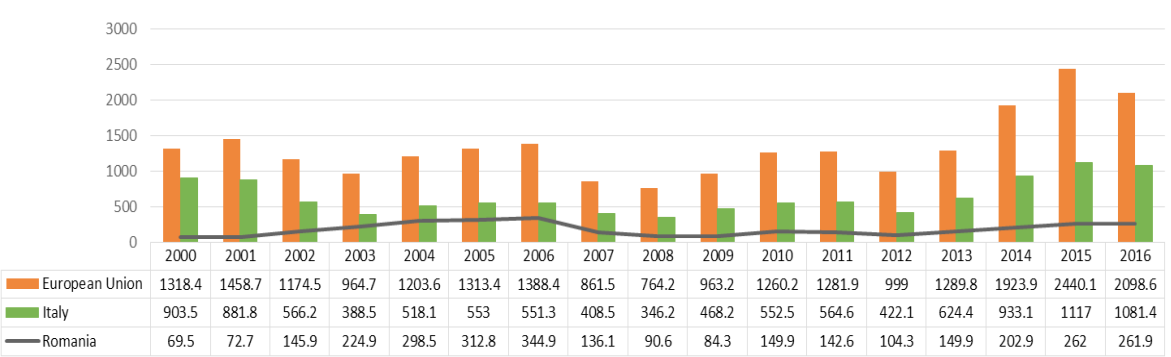

Figure 4. Total soybean production at European level - thousand tons Source: Eurostat-database, agriculture, INS

the EU and the number of member states grew, Italy ranked second place and an area with $2.17 \%$ less than of Romania, therefore Romania became first on soybean cultivated area.

Until Romania joins the European Union, period 2000-2007, there can be seen (fig.1) that the areas cultivated with this crop were quite large due to the genetically modified soybean varieties that were introduced in the country in 1998. Therefore in 2000 Romania was the only European country that approved the cultivation of genetically modified varieties (Roundup Ready) highly resistant to herbicide. These varieties were adopted very quickly by Romanian farmers, so Romania was among the top 10 soybean producers in the world in 2006 (INFOMG- Romania). Correlating this information with the study „Use of Genetically Modified Plants in Romania” by Băiceanu (2015) and doing an analysis of the results obtained in the paper, there can be observed a correlation between total soybeancultivated areas and the use of genetically modified soybean varieties. It can also be seen the increased interest of the Romanian farmers towards this crop and also to the genetically modified varieties, in 2006 the genetically modified soybean cultures occupied about $68 \%$ of the total cultivated area.

If by 2007 the areas were about 200,000 ha cultivated with soybean on the territory of Romania, of which 137,000 hectares with genetically modified soybeans. From 2008 they begin to decrease, reaching a surface of 52,000 (Dinu et al., 2010). This is due to Romania's accession to the European Union where cultivation of genetically modified soy is prohibited.

Romania had to align with the other countries and comply with Directive 2001/18 / EC of the European Parliament and of the Council, therefore on 1 November 2006 the Ministry of Agriculture, Forestry and Rural Development publishes the Order No 730 witch „Approval of the deletion of genetically modified soy varieties "this order was published in the Official Monitor no. 918 of 13/11/2006.

Romania follow and respect the legal acts listed above and it can be seen a decrease of about $60 \%$ of the soybean cultivated surfaces in 2008 compared to 2007, remaining below 80,000 hectares until 2015 when the surface start to grow again. It can be also noticed an increases in soybean cultivated surface to $54 \%$ in the European Union (fig. 3)

While soybean production at national level is quite large, average yields are $75 \%$ below the European Union in 2000, with 51.1\% in 2007 and $20 \%$ in 2016 and this is due to obsolete technologies, Italy being the only state that 
Table 1. Soybean oil production at European level and for the main Union countries - thousand tons

\begin{tabular}{ccccc}
\hline TIME $/$ GEO & Europe & Italy & France & Romania \\
\hline 2000 & 2940 & 244.8 & 67.6 & 29.5 \\
\hline 2001 & 3314.5 & 230 & 114 & 28.2 \\
\hline 2002 & 3308.3 & 217 & 150 & 38.4 \\
\hline 2003 & 3290.5 & 313.2 & 128 & 34.6 \\
\hline 2004 & 2774.6 & 328.7 & 71.2 & 42.1 \\
\hline 2005 & 2900.2 & 337.6 & 79.4 & 44.7 \\
\hline 2006 & 2856.8 & 327.8 & 48.9 & 45.6 \\
\hline 2007 & 2952 & 323.2 & 61.2 & 48.1 \\
\hline 2008 & 2970 & 323.9 & 53.5 & 29.7 \\
\hline 2009 & 2828.5 & 289.9 & 102 & 6.4 \\
\hline 2010 & 2870.3 & 306.9 & 91.3 & 3.4 \\
\hline 2011 & 2794 & 259.4 & 117.2 & 9.5 \\
\hline 2012 & 2935.6 & 288.6 & 116.6 & 12.1 \\
\hline 2013 & 3037.7 & 284 & 98 & 23 \\
\hline 2014 & 3257.6 & 278 & 108.1 & 24.9 \\
\hline $\begin{array}{c}\text { Average } \\
2000-2014\end{array}$ & 3002.04 & 290.2 & 93.8 & 28.01 \\
\hline
\end{tabular}

Source: Eurostat Database, agriculture, Faostat Statistics

managed to have an average production over the European Union for the entire analyzed period.

Figure $3 . \quad$ Average soybean production at European level - $\mathrm{kg} / \mathrm{ha}$ Source: Eurostat-database, agriculture, INS

Soybean culture has re-come in to attention for Romanian farmers with the new forms of support granted through Order 619/2015 on the approval of payment schemes that are applied in agriculture in the period 2015-2020, but also because of the high demand for soybean or soy products at national level, for human consumption and also for consumption/utilization in the zootechnical or industrial sector.

Analyzing the total production of soy there can be noticed that the highest yields were recorded in 2005 and 2006 when soybean oil production also reached the highest level. Comparing the year 2016 with 2000 we see an increase in production of $276 \%$ and in comparison with the years 2007 and 2014 we notice an increase of $92.4 \%$ and respectively $29 \%$, a decrease of $0.04 \%$ is noticeable compared to 2015.

Compared to Italy's soybean production, Romania recorded lower production on average by $68 \%$, the most representative years being 2016 and 2012 with $75 \%$ below Italian production, in 2007 with $66.6 \%$ and in 2000 by $92 \%$.

Romania's share of the soybean production in the European Union is $13.8 \%$ on average, while
Table 2. Food supply quantity (kg/ capita/yr.) for soybean oil

\begin{tabular}{cccc}
\hline TIME /GEO & Europe & Italy & Romania \\
\hline 2000 & 2.23 & 3.88 & 0.65 \\
\hline 2001 & 2.6 & 3.92 & 0.74 \\
\hline 2002 & 2.6 & 3.91 & 0.72 \\
\hline 2003 & 2.53 & 1.98 & 1.04 \\
\hline 2004 & 2.26 & 2.12 & 1.13 \\
\hline 2005 & 2.54 & 3.82 & 1.06 \\
\hline 2006 & 2.88 & 5.2 & 1.13 \\
\hline 2007 & 3.08 & 6.51 & 1.54 \\
\hline 2008 & 3.04 & 6.26 & 1.48 \\
\hline 2009 & 2.79 & 5.91 & 0.62 \\
\hline 2010 & 2.81 & 6.16 & 0.27 \\
\hline 2011 & 2.8 & 6.14 & 0.58 \\
\hline 2012 & 2.78 & 5.72 & 0.6 \\
\hline 2013 & 2.79 & 5.62 & 0.65 \\
\hline 2014 & 2.70 & 4.80 & 0.70 \\
\hline Average & 2.70 & 4.80 & 0.86 \\
\hline $2000-2014$ & & & \\
\hline
\end{tabular}

Italy has an average share of $47.5 \%$ in the whole analyzed period.

According to soybean processing technology in the production of oil (Găgeanu, 2012) and other by-products, it appears that from $6-6.6 \mathrm{~kg}$ of soy beans result in 1 liter of soybean oil, thus reporting the total yields to the quantities of oil we observe that not all the grain is intended for the production of oil, some of them can also go for export, depending on the manufacturer's wish.

At the national level, a quantity of 24.9 thousand tons of soybean oil was produced in 2014, representing $0.76 \%$ of the total European Union, for the same year Romania produced soybean oil 76\% less than France and 91\% less than Italy. The quantities of soybean oil obtained at national level did not exceed, for the analyzed period, 50 thousand tons, the highest quantity being recorded in 2007 by 48.1 thousand tons, at the opposite the smaller quantity is recorded in 2010 with just 3.4 thousand tons of soybean oil (Tab.1).

Romania's share in the European Union for soybean oil production is on average $0.93 \%$ while Italy has an average share of $9.73 \%$ and France an average share of $3.1 \%$ for the whole analyzed period.

The consumption of soybean oil in Romania per capita/year recorded the highest value in 2007 with a consumption of 1.54 liters being 
Table 3. Maximum annual consumption of soybean meal per animal species

\begin{tabular}{ccc}
\hline Species & UVM $^{*}$ & $\begin{array}{c}\text { Annual consumption / } \\
\text { soybean meal Kg }\end{array}$ \\
\hline Milk cow & 1UVM & 365 \\
\hline $\begin{array}{c}\text { Bulls, cows and other bovine animals for more than 2 } \\
\text { years, equate, over 6 months }\end{array}$ & 1,0 & 365 \\
\hline $\begin{array}{c}\text { Bovine animals between 6 months and 2 years } \\
\text { Bovine animals less than 6 months }\end{array}$ & 0,6 & 219 \\
\hline Sheep / goats & 0,4 & 146 \\
\hline Horses & 0,15 & 55 \\
\hline Breeding sows & 1,0 & 365 \\
\hline Growth / fattening pigs (180 days) & 0,5 & 250 \\
\hline Chicken meat (6 series / year) & 0,3 & 75 \\
\hline Laying hens & 0,014 & 0,7 \\
\hline Source: Ministry of Agriculture and Rural Development Romania & 0,03 & 7,5 \\
\hline
\end{tabular}

$136 \%$ higher than the consumption registered in 2000 , and by $120 \%$ compared to the consumption recorded in 2014 (Tab. 2).

Analyzing the production of soybean oil, consumption per population, during the period of 2000-2014 there can be seen that the average population is $22,596,921$ people with a mean consumption of $0.86 \mathrm{~kg} /$ year/person. The entire population consume an average of 19.45 thousand tons of soybean oil annual from an average of 28 thousand tons of soybean oil production per year, leaving about 8.55 thousand tons of oil for processing, industrialization or destined for export.

Outputs of the extracted oil resulted in byproducts (cakes) assigned for the livestock sector may replace the animal fat in the required fodder ratio. Soybeans have a high protein content of 41-48\% (He and Chan, 2013) may successfully be used for animals and birds, according to the consumption by each species (Tab. 3).

From the specific soybean processing technology, $6.6 \mathrm{~kg}$ of soybeans with a loss of $3 \%$ during the technological process $(0.2 \mathrm{~kg})$ will result in 1 liter of oil, $0.6 \mathrm{~kg}$ of shells, $0,8 \mathrm{l}$ of water and $4 \mathrm{~kg}$ of cakes (Boeru and Puzdrea, 1980), so that the total oil production resulted in an average of 112,000 tons of soy cakes for the analyzed period 2000-2014.

Each species needs different quantities of soybean cakes per year, so that an average of 2544 thousand cattle consumes a mean of 696 thousand tons of soybean cakes per year; a herd of 9128 thousand sheep/goats consumes an average of 502 thousand tons of soybean cakes per year; 752 thousand horses consume a mean of 274 thousand tons of cakes per year; a stock of 5611 thousand pigs consumes about a mean of 911 thousand tons of cakes/year; 80,000 birds consume an average of 328 thousand tons of cakes per year. This means that at the national level there is a need for 271, 1000 tons of soybean cakes per year to satisfy the zootechnic sector consumption

Analyzing average and total soybean production and soybean oil production as compared to annual per capita consumption, there can be seen that it can be supported by domestic oil production, but there remain small quantities of oil for processing or industrialization.

While the livestock sector in Romania needs about 2.7 million tons of soybean cakes annually, at national level 112 thousand tons are produced, meaning 95\% less than consumption.

Although Romania has favorable conditions for the production of soybean, it is not produced in sufficient quantity to satisfy all demands, so Romania needs to import soybean or soybean byproducts (Tab. 4).

Analyzing Romania's imports and exports of soybean and soybean by-products, there can be observed that beans, soybean oil and soybean cakes are imported/exported at national level. Comparing the exported quantities with the imported ones, we note that Romania imports on average $47 \%$ more soya beans than it exports, up to 19.5 million dollars.

During the period 2000-2014, there have been years in which soybean exports exceeded, while the most representative imports were in 2005-2006.

Also, on average, some 249.8 thousand tons of cakes / cakes per year are imported on the national 
Table 4. Trade with soy and soybean by-products in Romania

\begin{tabular}{|c|c|c|c|c|c|c|c|c|c|c|c|c|}
\hline \multicolumn{13}{|c|}{ ROMANIA } \\
\hline \multirow{3}{*}{ 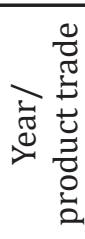 } & \multicolumn{3}{|c|}{ Import Value } & \multicolumn{3}{|c|}{ Export Value } & \multirow{2}{*}{\multicolumn{3}{|c|}{ Import Quantity }} & & \multicolumn{2}{|c|}{ Export Quantity } \\
\hline & \multicolumn{6}{|c|}{1000 US\$ } & & & & \multicolumn{3}{|c|}{ TONNES } \\
\hline & 它 & 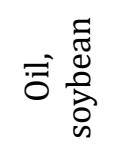 & 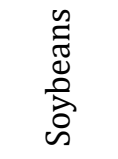 & 离 & 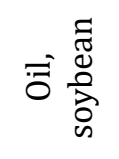 & 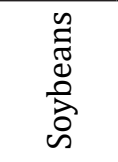 & 空 & 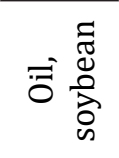 & 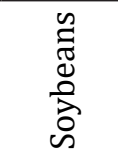 & 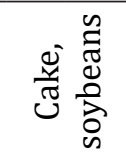 & $\overrightarrow{\tilde{\sigma}} \frac{\tilde{\pi}}{\stackrel{0}{0}}$ & 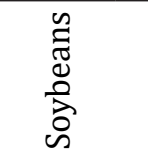 \\
\hline 2000 & 16088 & 196 & 2326 & 528 & 4827 & 443 & 74602 & 429 & 12197 & 2038 & 13398 & 24925 \\
\hline 2001 & 20421 & 97 & 20173 & 1145 & 4192 & 1902 & 90798 & 249 & 95864 & 4378 & 11437 & 8793 \\
\hline 2002 & 2392 & 7784 & 31344 & 244 & 143 & 177 & 107664 & 16777 & 141703 & 10197 & 2954 & 766 \\
\hline 2003 & 23607 & 652 & 13646 & 2691 & 792 & 6874 & 99191 & 966 & 54391 & 984 & 13988 & 24784 \\
\hline 2004 & 33926 & 96 & 16866 & 2161 & 13251 & 3935 & 118109 & 82 & 45131 & 7347 & 22266 & 13164 \\
\hline 2005 & 24488 & 88 & 989 & 4174 & 9545 & 12453 & 88135 & 109 & 1166 & 16503 & 17083 & 49779 \\
\hline 2006 & 21986 & 956 & 4309 & 1657 & 13855 & 12877 & 81554 & 1264 & 11945 & 6685 & 23891 & 54217 \\
\hline 2007 & 73289 & 8497 & 32584 & 231 & 12686 & 6461 & 217039 & 8413 & 68559 & 65944 & 16247 & 22091 \\
\hline 2008 & 155253 & 14472 & 55699 & 33642 & 12915 & 19858 & 315012 & 12619 & 94361 & 66237 & 9866 & 38989 \\
\hline 2009 & 199626 & 3288 & 10997 & 46002 & 3557 & 4233 & 469191 & 4094 & 20762 & 103339 & 4434 & 10445 \\
\hline 2010 & 175532 & 328 & 7947 & 30194 & 712 & 17554 & 435214 & 3507 & 15628 & 71839 & 764 & 36942 \\
\hline 2011 & 195113 & 5126 & 1802 & 34346 & 1211 & 39524 & 455343 & 4279 & 34388 & 80678 & 801 & 72716 \\
\hline 2012 & 238186 & 4017 & 3833 & 53333 & 2573 & 53718 & 481563 & 3178 & 63325 & 104986 & 1912 & 8951 \\
\hline 2013 & 262457 & 5283 & 71353 & 69044 & 12942 & 29109 & 463731 & 4545 & 117277 & 11706 & 12919 & 38854 \\
\hline 2014 & 103026 & 3634 & 19562 & 19957 & 6657 & 14937 & 249796 & 4322 & 55478 & 39490 & 10854 & 28958 \\
\hline 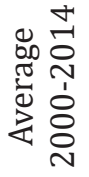 & 103026 & 3634 & 19562 & 19957 & 6657 & 14937 & 249796 & 4322 & 55478 & 39490 & 10854 & 28958 \\
\hline
\end{tabular}

Source: Eurostat Database, agriculture; Faostat Statistics, trade; Trade map atlas.

level in the amount of 103 million dollars and they export 210 thousand tons less in the amount of 19.9 million dollars, the situation is different for the oil of soybean, Romania exports oil on average 10.8 thousand tons worth 6.65 million $\$$, and the imported quantity is on average 4.3 thousand tons worth 3.6 million \$.

\section{Conclusions}

In the present paper there has been presented the situation of soybean culture from 2000 to the 2016, highlighting the alimentary consumption of soybean and the consumption of oil per capita.

The analyzed period 2000-2016 comprises two well-defined parts: the pre-accession and post-accession period of Romania to the European Union, clearly highlighting certain aspects such as the use of genetically modified soybean varieties and surfaces cultivated with them, the forms of support as well as imports and exports to Romania.

Regarding the genetically modified soybean since 6.11.2013, the European Union has authorized, with the agreement of the European Food Safety Authority (EFSA) on the safety of human and animal health and the absence of environmental risk, another 7 types genetically modified soybean in addition to the existing 8 , they have not yet been experimented on the territory of Romania, but there are certain products that are imported and marketed on the territory of Romania containing soybean modified according to the conditions imposed by the European Commission on labeling and traceability.

\section{References}

1. Băiceanu A (2015). Use of Genetically Modified Plants in Romania

2. Bertheau Y, Davison J (2011). Soybean in the European Union-Status and perspective. In D. Krezhova (Ed.), Recent trends for enhancing the diversity and quality of soybean products. Rijeka, Croatia: InTech.

3. Boeru G, Puzdrea D (1980). Technology of vegetable oils. Technical Publishing House, Bucharest.

4. Catalog of Plant Varieties of Romania for the year 2015 developed by the State Institute for Testing and Registration of Soils (ISTIS)

5. Dinu T, Alecu IN, Stoian E (2010). Assessing the economic impact and the traceability costs in the case of banning the cultivation of GM soybean in Romania. Scientific papers 
series management, economic engineering in agriculture and rural development, 10(2): 61-66

6. Directive 2001/18 / EC of the European Parliament and of the Council

7. DG-AGRI (www.ec.europa.eu/agriculture/index_en)

8. Eurostat Database, agriculture.( http://ec.europa.eu/ eurostat)

9. Faostat Statistics-Trade. (www.fao.org)

10. Găgeanu P (2012). Primary preparation of seeds for extracting vegetable oil. INMA Bucharest

11. He FJ, Chen JQ (2013). Consumption of soybean, soy foods, soy isoflavones and breast cancer incidence: Differences between Chinese women and women in Western countries and possible mechanisms. Food Science and Human Wellness, 2(3-4): 146-161

12. INFOMG- Romania. (http://www.infomg.ro)
13. Ministry of Agriculture and Rural Development. (www. madr.ro/en)

14. National Institute of Statistics of Romania (www.insse.ro)

15. Oilseeds: World Markets and Trade. Circular Series FOP 045-13 Foreign Agricultural Service, United States Department of Agriculture (May 2013)

16. Order No 730 publicized by the Ministry of Agriculture, Forestry and Rural Development

17. Project „Facilitating the trade in agri-food products in the Black Sea Basin (FTAP)” Project number: 1.1.1.66031.77 MIS-ETC 185 -SUDIU STUDY „Research on the regional market of oilseeds for the expansion of cross-border trade opportunities: Moldova, Romania, Ukraine "

18. Soy Stats (www.soystats.com)

19. Trade map atlas (www.trademap.org) 